\title{
The Nexus between Innovation and Business Competitive Advantage: A Conceptual Study
}

\author{
T. T. Onileowo ${ }^{1,2, *}$, F. M. Muharam ${ }^{1}$, M. K. Ramily ${ }^{1}$, Saleh F. A. Khatib ${ }^{1}$ \\ ${ }^{1}$ Azman Hashim International Business School, Universiti Teknologi Malaysia, Johor Bahru 81310, Malaysia \\ ${ }^{2}$ Department of Entrepreneurship, Faculty of Management Sciences, Ekiti State University, Ado-Ekiti, Ekiti State, Nigeria
}

Received March 16, 2021; Revised May 7, 2021; Accepted May 28, 2021

\begin{abstract}
Cite This Paper in the following Citation Styles
(a): [1] T. T. Onileowo, F. M. Muharam, M. K. Ramily, Saleh F. A. Khatib, "The Nexus between Innovation and Business Competitive Advantage: A Conceptual Study," Universal Journal of Accounting and Finance, Vol. 9, No. 3, pp. 352 - 361, 2021. DOI: 10.13189/ujaf.2021.090309.
\end{abstract}

(b): T. T. Onileowo, F. M. Muharam, M. K. Ramily, Saleh F. A. Khatib (2021). The Nexus between Innovation and Business Competitive Advantage: A Conceptual Study. Universal Journal of Accounting and Finance, 9(3), 352 - 361. DOI: 10.13189/ujaf.2021.090309.

Copyright $\odot 2021$ by authors, all rights reserved. Authors agree that this article remains permanently open access under the terms of the Creative Commons Attribution License 4.0 International License

\begin{abstract}
Despite the fierce competition in the business environment, firms accept relatively low innovative solutions in their daily activities and consequently lose competitive advantage, experience creeping growth at a snail's pace directly associated with the firm's inadequate finance and eventual collapse. This study examined the interrelationship between access to finance, innovation, and competitive advantage. Premised on the study findings, results revealed that innovation is an all-important strategy that differentiates the products and services of business firms and consequently sustaining competitive advantage. The results suggest that adequate financing can be a mechanism by which innovation and competitive advantage positively relate to increased performance. The strength between these variables would be heightened as access to finance increased. It was further established that firms with encouraging innovative culture would gain rare core competencies and maintain the position of the market leader while sustaining competitive advantage. Based on these findings, the study recommends that business firms conduct market surveys to determine the need of current and prospective customers. Management should prioritize, invest heavily in research and development, and the government should strive to provide adequate financial support, infrastructural facilities, and incentives for business operations.
\end{abstract}

Keywords Innovation, Business Competitive Advantage, Business Firms, Access to Finance

\section{Introduction}

Innovation is an all-important influence of growth, competitiveness, profitability, and sustainable delivery of value-added products and services [1]. The urgent need for innovation springs from the increasing competition in the business environment; amid the increasing competition and technological growth noticed in the business environment, innovative products and services grow rapidly, making them highly distinguishable [2]. Innovation refers to the series of mental activities involved in causing creative development or implementing ideas targeted at increasing the features of certain products or services towards delivering optimal products or services to customers [3]. For business firms desiring to excel, one most significant pathway is to innovate; the integration and sustenance of innovation will attract a noticeable competitive advantage for the firm and shoot up its position in the market [2]. The business environment has been characterized by intense competition, which undoubtedly affects the firm's environment and the decision-making process adopted by the management. Conto et al. [4] suggested that over the years and most especially in this current century, the increased market globalization experienced has noticeably enhanced a firm's approach to competition; this is in their bid to ensure that their survival or going concerned is 
sustainable. The common need to introduce new things that appear distinct or improved to consumers demonstrates the height of competition adopted by business firms which consequently improves customers' loyalty and ultimately sustains the firm's existence in business [4]. However, this lack of a high level of innovation among firms might be due to the lack of understanding of the benefit that can be brought to firms from innovation, which can increase organizational productivity, profitability, and sustainability.

Moreover, access to adequate financing is one of the major concerns responsible for Nigeria's low gross output. Access to finance is critical for business success, viewed as a backbone to every business [5, 6]. Generally speaking, the term financing is vast, and all over the world, there is no agreement and universal agreement to what constitutes it because of its scope, which is very broad. Financing is described from the context and the perspective of every scholar defining and explaining the word; hence, there is generally no agreed meaning. Nevertheless, finance manages funds that involve savings, investing, leasing, budgeting, planning, and forecasting. It can also be internal or external. The firm's primary internal funding source is retained earnings, or revenue accrued over time but not distributed to shareholders. Internal funding is usually preferred over external financing since the latter can be incredibly expensive [7].

In consequence, there are ventures that firms would prefer to pursue if they had adequate internal capital, but that will not be pursued if they need external funding to grow. In several instances, businesses are unable to obtain external funding. On the other hand, debt and equity (or certain hybrid forms), private investors (such as business angels), investment firms, banks, and financial markets (among others), comprises external sources of funding. Debt is usually preferred to equity if external funds are required since debt is traditionally a less costly funding source (even though still more costly than internal funds). Lee \& Chew-Ging [8], show that the bulk of funds for research and development in the private sector appear to come from internal or own resources. The result indicates that innovating firms lack appropriate financing sources as an important factor in hampering innovation activities. Financing can be used to describe projects related to banking [9], financial debt or credit, financial markets, cash, and acquisitions. It can also mean the method of obtaining funds for commercial purposes, acquisitions, or investments. It comprises funds, banking, credit, savings, liabilities, and assets. It can also mean the process of providing funds for business activities, making purchases, or investing. Financing is based on the principles of raising the initial capital needed for a business venture, the nature of the securities to issue, how and to whom they should be sold, how best to utilize the funds that are secured together with their proper appointment for a plant, equipment and working capital [10]. Finance or financing can be considered one of the main factors deciding the growth, continuity, or failure of any business enterprise. Kelley et al. [59] thought that funding is one of the main essential tools that promote economic activity in many nations.

Therefore, the availability of finance can be recognized as one of the most important conditions in the innovation process. Having financial capital will ensure innovative start-ups and turn innovative ideas into practice [11]. Therefore, having financial capital will boost business performance. In the same view, Aziz \& Samad [48] assert that innovative businesses that are financially independent are said to have more capacity to develop and stay competitive in the market. Okundaye [60] believes that the lack of adequate finances faced by small enterprises relative to large corporations has more significant effects for small firms than for large firms, thereby limiting the potential of business owners to build or sustain competitive advantages [12]. Relevant access to valuable market capital, such as financial resources, is, therefore, one of the essential and crucial factors that have taken entrepreneurial activity to the fore in any economy [13, 14].

Based on the preceding, it can be concluded that the availability of funds facilitates further investment opportunities, making it easier for firms to invest in innovation to gain a competitive edge; the more innovativeness, the greater the competitive advantage over other competitors. Acharya et.al [49] argued that high leverage could contribute to under-performance of the commodity market. However, access to funding interventions can be viewed from two perspectives: financial institutions or fund users. Likewise, Honig et al. [50] concluded that start-ups with access to social and financial resources are more likely to innovate and compete in the same way as their contemporaries in business operations. According to several reports, a firm's optimum performance is linked to its ability to access the requisite financial capital $[15,16]$. Globally, the finance industry has expanded in recent years, with various implications for innovation and development. Financial development will promote innovation practices by removing liquidity constraints on capital inflows to the most productive ventures by fostering improved competitive advantages leading to growth $[17,18,19]$.

Moreover, despite the fierce competition in the business environment, business firms accept relatively low innovative solutions in their daily activities, lose competitive advantage, and experience creeping growth at a snail's pace, directly associated with the firm's consistent drop in revenue eventual collapse. Several works $[4,21,25]$ have focused on the association between innovation and competitive advantage in developing countries; however, none of these studies have documented the interrelationship between finance, innovation, and competitive advantage. Hence, this study 
explored the moderating effect of access to financing on the relationship between innovation and a firm's competitive advantage, using secondary data obtained from previous studies by the authors and selectively using empirical evidence to support the researcher's arguments. The study found that adequate financing can be a mechanism by which innovation and competitive advantage are positively related to improving performance. The strength of the interaction between these variables would be heightened as access to finance increased [6].

Notwithstanding the significance of this issue, especially in recent times, most researches in literature emphasizing the noticeable role of innovation in driving competitive advantage have not tracked the moderating effect of financing on the relationship between innovation and competitive advantage $[20,21,22,23,24,25,26,1]$. Hence, this study contributes to the existing works of literature on financing, innovation, and competitive advantage, by analyzing the importance of adequate financial access in enhancing firms' performance as well as encourage investment in innovation, motivate firms to perform research, implement appropriate technology for development projects to increase competitive advantage and the need for firms to understand the benefits that can be brought to them from innovation, as this would guarantee organizational productivity, profitability in a bid to achieve a sustainable going concern. Kerr \& Nanda [27] provide evidence that young, high-tech, publicly-traded firms finance their $R \& D$ investment almost entirely through internal cash flow and external equity markets. Hence, a proper-functioning financial market plays a central role in driving economic growth through its ability to spur technological innovation [28]. The research robustly demonstrates the moderating effect of financing on the relationship between innovation and competitive advantage as a fulcrum for the entrepreneurial firm's growth and sustainability in a competitive business environment [29].

\section{Innovation}

Innovation refers to the series of actions involved in causing creative development or implementing new ideas to increase the elements and usefulness of certain products and services towards delivering additional benefits to target customers Fichman [51]. Innovation is the extent to which new knowledge and technology are converted into valuable goods and services for domestic and global markets, resulting in increased value for consumers [8]. It encompasses a broad range of activities to improve business performance, such as introducing a new or substantially improved good or service, delivery process, production process, business model, or management structure [30].

Innovation has been described as the most significant part of globalization, firm value, and competitiveness [31]. The increasing pace of globalization and international competition occasioned the urgency of innovation, especially technological innovation. It has become the most effective method required by every business firm to compete in the local and international markets. Both internal and external forces can influence a firm's ability to innovate. Internal factors concern the firm's intangible assets, including patents, skills, vast experience, workforce strength, research and development, organizational structure, intellectual properties, and employees' capacity. However, external factors refer to a firm's relationship with its external environment, including customers, suppliers, and competitors [26].

The reward that occasions motivate business firms is numerous; they include increasing market share, value-added product, the domination of a new market, and customer loyalty. Innovation involves a systematic process as it affects practically every activity of the firm, starting from the initial research-development to the activities that create the product or services; this suggests that innovation impacts significantly on every function of business firms [1]. The outcome of consistent innovative activity is demonstrated in products or services with distinctive quality and optimality; most importantly, production processes guaranteeing an improved environment also reveals the height of innovation integrated by a firm and protect the corporate image despite contributing to the sustainable growth of the firm.

The significance of innovation and its association with competitive advantage have been severally emphasized over time. Hitt et al. [52] maintained that innovations are important due to their distinctive and strategic differentiation of a firm's products and services from competitors, thereby occasioning an additional value for customers. Paiva et al. [53] averred that innovation describes any process that guarantees change; it involves managing an organizational activity to reach a potential competitive advantage for firms. The potency of innovation and the significant impact on productivity growth has been observed in some developed countries to have wrongly affected the expansion of economic and social space of numerous regions, cities, and countries, thereby driving massive development as the success of business firms beget a developed society [23]. Similarly, OECD [61] affirms that firms strive to innovate to increase profit and acquire core competence over their competitors sustainably. Hence, innovation is a financial and economic outcome of adopting certain technology or introducing an idea into the process of an organization to achieve business growth.

\section{Competitive Advantage}

Over time, the markets of practically all businesses 
have been increasingly complex and volatile, requiring management of business firms to observe and follow the developments in the market with constant innovation towards gaining competitive advantage. Competitive advantage has been described as all-important in the competitive business [32]. Tarus et al. [25] perceived competitive advantage to reduce costs, differentiating products, services, or effective implantation of focus strategy in a business firm. It was further affirmed that competitive advantage increases following the firm's value to its customer's satisfaction while improving business performance. Porter [24] advanced that the common approach firms can employ to attain a competitive advantage would be to develop a market strategy aligned with market growth and consistent with the firm's capital and competence that can be achieved by sustainable innovation.

Competitive advantage indicates the constant production of value-added products or services for customers by a business firm relative to products offered by competitors; it also describes the production of a product or service by a firm at a relatively reduced cost [33]. According to Saloner, et.al [54] firms striving for survival and sustainability must frequently review the value it dishes out and maintain a competitive advantage. Therefore, it has become urgent for firms to use existing core competencies while exploring new ideas to tackle the intensifying competition among firms and the pace of development in the industry [34]. This can be attained with adequate differentiation, which can be reached with the provision of optimal service and valued products, creating reputable brands that guarantee a long-term relationship with customers [35].

The ability of a firm to maintain its increasing performance in a manner that competitors find hard to co-opt is a competitive advantage [36]. A competitive advantage is a strategic approach that has been mentioned in recent management literature. Its success stems from the rapid growth that firms experience today, the hyper-competitive nature of the business environment, the effect of unstructured markets and globalization, the increasing needs of consumers, and the increasing pace of development in information technology and communication [37]. Managers of business firms tend to assess and select strategies that ensure improved performance for their business with a relatively rare advantage. Such advantages are often found in the cost structure of the business and the ability of a firm to make a significant difference between its business and that of its competitors [38].

\section{Finance-Innovation Nexus}

The increasing pace of globalization and international competition occasioned the urgency of innovation, especially technological innovation. It has become the most effective method required by every business firm to compete in the local and international markets [26]. A well-established capital markets promote industrial development via incentive to start-ups [39]. A variety of studies led credence to Schumpeter [71] assertion that banks promote innovative activities [40, 41]. According to these reports, banks facilitate technical growth by allocating capital to entrepreneurs with the most innovative career prospects, including technological advances and manufacturing processes, thus, confirms that by providing the resource distribution process, the country's financial sector has a major impact on development activities and provides valuable banking services (along with knowledge transfer and financial reporting) that contribute to the efficiency, minimize costs, and promote long-term growth in creative entrepreneurial development [14].

According to Zang \& Kim [32], a stable financial structure reduces organization expenses, resulting in a greater cash inflow to the innovation market, accelerating innovation. These scholars argue that a well-established financial structure is a key factor in increasing the number of patent applications filed in those countries, and thus a driving force for development. According to Rajan \& Zingales [55] in more economically developing countries, industries that are more reliant on external funding develop much faster. Financial development plays an important part in developing and maintaining innovation-based economies, as confirmed by Aghion et al. [63] innovation-based growth model. Financial development lowers the cost of monitoring and reporting operations, minimizing agency costs and encouraging organizations to participate in innovative activities.

In a similar vein, Hyytinen \& Toivanen [62] shows that imperfections in the financial sector stifle growth and innovation in Finland, suggesting that government policy is critical in addressing financial market imperfections. On the other hand, according to Morck \& Nakamura [64], credit markets deter industries from investing in creative ventures due to their natural preference for risk-free investments. Hsu et al. [14] demonstrated that the growth of credit markets stifles innovation in industries that are highly dependent upon external sources of finance and are technologically intensive. Financial growth, according to Ang [65], is essential for reducing market resistance and promoting technology-based practices. Barbosa \& Faria [66], affirmed that financial market policy is an important indicator of innovation growth, and financial development facilitates technological innovations by increasing knowledge flow and thus promoting access to credit facilities for industries, particularly technology start-ups. Maskus et al. [67] revealed that lending rate from banking sector, capital stock, including bond market all have a major effect on the rate of innovation. More recently, Hsu et al. [14] discovered that financial market growth deters innovation in sectors that depend mostly on external 
financing and are technologically intensive. According to Pradhan, et.al [68], the development of the financial sector and improved creative potential in European nations results in long-term economic growth. The financially activated economy, according to $[15,69]$, will encourage innovative activities by removing credit constraints on the flow of capital to the most successful projects and encouraging greater competitive advantage leading to growth. Rysin et.al, [28] in their works, established that the main factor underlining the strengthening of the role of finance in recent decades is the rapid growth of commodity-money and credit-money relations, which suggest there is a trend towards a constant increase in commodity flows both within countries and in the field of international trade, for the service of which it is necessary to increase financial flows similarly. Thus, an increase in financial flows and an increasing volume of use of financial instruments lead to an increase and intensification of competition, both between individual entities and between entire sectors of the financial market.

Undoubtedly, from the preceding, having a high degree of access to finance will assist a business in obtaining required financing, and, as a result, businesses are more likely to expand. Increased access to finance would result in higher innovative projects, expertise, knowledge, and improved performance.

\section{Finance- Competitive Advantage}

Businesses can make profits by offering products and services on the market at prices greater than the cost of producing such goods and services. In an industry, firms never exist alone; competition is typically a core component of any marketplace. A firm must strive to gain an advantage over its rivals and make a profit to survive. By delivering valuable services to the customer, the firm gains a competitive advantage by being better off than its rivals [42]. It may also refer to a business's low costs, a competitive advantage, and a well-defined strategy. The value a firm can produce for its customers must outweigh the cost of producing it for the firm to have a competitive advantage. The only way for businesses to achieve a competitive edge is to develop a strategy that is aligned with the business's market dynamics and relevant to the firm's resources and capacity, which can be accomplished through the product innovation process [33]. Various scholars have described competitive advantage in several ways. For example, Porter [70] showed that competitive advantage refers to the marketplace's comparative positional leadership that enables a firm to outperform its competitors. Iriyanto et al. [43] described competitive advantage as improved efficiency, improved quality, increased productivity, or cost reductions. Concurrently, Rothaermel [56] described competitive advantage as a firm's formulation and execution of a policy that leads to superior performance when compared to its competitors in the market. Therefore, competitive advantage is described as a firm's capacity to provide more value to its customers than any of its competitors, thereby gaining a relative advantage position [44]. Based on the preceding discussion, a competitive advantage is the outcome of a strategy design mechanism implemented by a business to provide consumers with additional benefit (differentiation and low cost), leading in a competitive advantage for the business over time.

Besides, scholars and policy-makers approve that businesses are a major driver of economic development. They were also thought to be especially vulnerable in the external world to uncertainty and instability. Most policymakers recognize that business requires adequate support for sustainability and success. Historically, such assistance has been provided in a bid to promote the external environment. Such facilitation would be beneficial only if the firm has the internal capacity to benefit from external facilitation [45]. Entrepreneurs and government agencies are important players in capital expenditure projects and regulatory enhancements to sustain business growth [46]. Business support encompasses a broad range, beginning with the implementing and extending financial support, training and marketing, and advisory services. Research and innovation, education, financial support, industrial equipment, sales, and advisory support are the six categories in which these support services can be classified [47].

Sentsho et al. [57] identified that the tax rate is typically perceived as prohibitive for business competitiveness. It entails special rates, as is the case in many developed countries, to minimize tax burdens on businesses. Since administrative processes and their expenses do not differ between small and large businesses, some legislation is also not encouraging. Support services aimed at providing and promoting sustainable growth for small enterprises have been thoroughly addressed in previous studies. Among the initiatives funded by the support programmes are budgetary and investment, technology and skills development, training and consultancy, public investment, and marketing and product development [48]. Therefore, the need for government intervention by providing businesses with financial support as access to finance is considered a major challenge confronting most businesses worldwide [49, 50].

According to Stevenson \& Lundström [58], the major reason government provides support for firms are to reinforce the existing structure of start-ups by working to ensure that they are able to compete in the market place and not constrained by their small scale [51]. Such financial provision comprises the provision of funds directly and indirectly aimed at improving the performance of firms in the competitive market, providing guidance and soft advice to firms on a wide range of subjects, promoting start-ups via initiatives ranging from loans, government grants, and 
education [50]. Based on the preceding, this study advocates that adequate financial access would facilitate and strengthen the existing business base by working to ensure they are able to compete in the marketplace without being constrained by their smaller position [52].

\section{Nexus between Innovation and Business Competitive Advantage}

It has become necessary to track adequate financing and its potential in facilitating innovative firms in creating a competitive advantage for business firms. It is usual and the responsibility of managers to explore every option to ensure the organization's survival in the present and, looking forward, the sustainable growth of business activities with numerous strategic ideas employed towards occasioning differentiation and increased competitiveness [4]. In the series of activities involved towards achieving these goals, it is expected that challenges surface and that firms make an all-out effort towards adapting to the situation, if possible, in a distinct way that demonstrates core competence over competitors. Following this idea, to attain lasting competitive advantages, important methods and features utterly new in the market, either internal or external, must be implemented by the firm. Based on this premise, financing is necessary as a factor that guarantees the attainment of competitive advantage. Business firms function in a hyper-competitive environment, and one effective approach to tackling the competition is the usage of strategies targeted towards bolstering the system in the market [4].

$[54,55]$ maintained that the sample of strategies that firms will adopt to tackle the challenges and the approach used should harness the prevailing opportunities, resulting in the attainment of competitive advantages. Although Beheshti [46] posited that firms must consider the available resources (funds), this can pose a difference in the creation and sustainability of competitive advantages. Given this constraint, firms achieve a competitive advantage when it introduces strategies and innovations that can create unusual value for the market. A firm with a competitive advantage over its competitors is one that receives superior financial returns in its business over time [53]. As a result of this, innovation may be the primary system for a business firm to sustain a competitive advantage over other competitors. With a significant reduction in costs, the introduction of promotional methods, and consistent innovation to provide value-added products to the market, highly distinctive competitive advantage can be achieved. In connection with this aim, the difference between the product or service and its competitors must be reviewed and maintained over time. When business competitors are incapable of copying a firm's strategy, the competitive advantage becomes sustainable [54]. In this way, the existing nexus of financing, innovation, and competitive advantage exists in the expectation that firms must efficiently use their resources in an approach that demonstrates adequate innovations aimed at reaching competitive advantage [55].

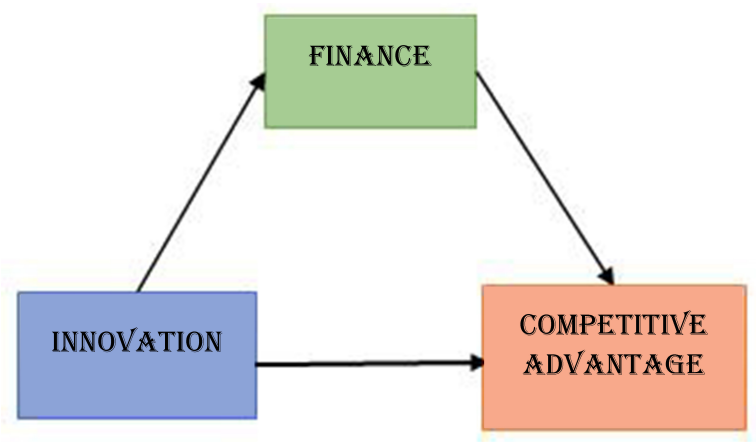

Source: Prepared by the authors.

Figure 1. The Interrelationship between Finance, Innovation, and Competitive Advantage

The framework in Figure 1 illustrates the interrelationship between access to finance, innovation, and competitive advantage. As discussed in the preceding sections 2 to 6 , the framework was derived from understanding the whole study comprehensively. The research framework shows that access to financing can directly impact innovation and competitive advantage, respectively. Finance is essential to innovation because it enables organizations to perform research, implement appropriate technology for inventions, and create and commercialize innovations (among others). Firms face a significant challenge in obtaining external funds for innovation. Firms can use a range of financing instruments offered by various financial intermediaries and investors to finance their investment projects. Access to external sources of finance is often particularly difficult at the seed and beginning stages of a company's growth since businesses at this stage face high barriers to financing, particularly because they lack a proven record. Hence, the need to establish a transparent, broad, and effective enabling policy environment for investment and build the human and institutional capacities to implement them. Also, access to finance can help the existing relationship between innovation and competitive advantage, in the sense that it shows the effect of financing on innovation towards improvement, formation, and enhancement of businesses to increase firm's competitive advantage, as this would yield expansion and, also contributes to achieving a sustainable development generally. It is indisputable to argue that access to finance encourages innovation; the growth and sustainability of any business organization depend on their access to finance. The contribution of this study will be of importance to managers of a business, as this would pinpoint the importance of the different sources of finance available to them. 


\section{Conclusion and Recommendations}

This study examined the interrelationship between access to finance, innovation, and competitive advantage. Most studies in literature discussing the prominent role of innovation in achieving competitive advantage have not documented the existing relationship between finance, innovation, and competitive advantage. The study contributes that access to finance can be a mechanism through which innovation and competitive advantage positively relate to increasing performance. Also, the strength of the relationship between these variables would be heightened as access to finance increased. With appropriate finance, firms will be motivated to invest in innovation, conduct research, implement appropriate technology for development projects needed to boost their competitive position in the marketplace. Thus, it becomes one of the important contributions of this study because it explains how finance access affects firm performance.

The research also found that innovation is an all-important strategy that differentiates the products and services of business firms and, consequently, sustains business competitive advantage. Hence, firms with an encouraging innovative culture would gain rare core competencies, thereby shooting up their position in the market. The fact that most firms encounter problems in financing innovation implies that there might be a role for government support. Based on this premise, it becomes urgent for business firms to consistently carry out market surveys towards ascertaining the need of current and prospective customers; management should prioritize and invest heavily in research and development as it encourages innovation and improves competitive advantage, the government should strive to provide adequate financial support, infrastructural facilities as well as incentives for business firms, this will create an enabling business environment and also save businesses from collapsing amid intense competition. This study will be useful because it will encourage various financial intermediaries to give support to business enterprises, knowing that their contribution towards economic development cannot be undermined. It will assist the policy maker when making strategic deliberations regarding economic growth to give consideration to businesses, as this would heighten their knowledge about the existing challenges and factors that encourage innovation and competitive advantage to improve Nigeria's economic prosperity. Given that no empirical investigation was included in this research, we encourage future research to empirically investigate the interrelationship between access to finance, innovation, and competitive advantage.

\section{REFERENCES}

[1] A. Ionescu and N. R. Dumitru, "The Role Of Innovation In Creating The Company's Competitive Advantage," Economic Forum, vol. 4, no. 1, pp. 99-104, 2015.

[2] S. Zainurossalamia, D. Setyadi and S. Rusmilawati, "The Effect of Innovation on Firm Performance and Competitive Advantage," European Journal of Business and Management, vol. 8, no. 29, pp. 113-120, 2016.

[3] I. Noorani, "Service Innovation and Competitive Advantage," European Journal of Business and Innovation Research, vol. 2, no. 1, pp. 12-38, 2014.

[4] S. M. Conto, J. V. Antunes Junior and G. L. Vaccaro, "Innovation as a competitive advantage issue: A cooperative study on an organic juice and wine producer," Gestão \& Produção, SciELO Brasil, vol. 23, no. 2, pp. 397-407, 2016.

[5] J. Wiklund and D. Shepherd, "Entrepreneurial orientation and small business performance: A configurational approach," Journal of Business Venturing, vol. 20, no. 1, pp. 71-91, 2005.

[6] R. K. Alharbi, S. B. Yahya and E. R. Ahmed, "Characteristics of manager's and SMEs performance: the role of access to finance as a moderator," International Journal of Engineering \& Technology, vol. 7, no. 4, pp. 5115-5119, 2018.

[7] A. O. Scoreboard, "Financing SMEs and Entrepreneurs," OECD iLibrary, 2020.

[8] C. Lee and L. Chew-Ging, "Encouraging innovation in Malaysia: Appropriate sources of finance," CACCI Journal, vol. 1, no. 1, pp. 23-28, 2007.

[9] A. Apătăchioae, "The performance, banking risks and their regulation. Procedia economics and finance," in 7TH International Conference on Globalization, and Higher Education in Education in Economics and Business Administration, Rome, Italy, 2015.

[10] W. Н. Lough, Business finance, Рипол Классик, 1919, p. 631.

[11] S. Adomako and A. Danso, "Financial literacy and firm performance: the moderating role of financial capital availability and resource flexibility," International Journal of Management and Organizational Studies, vol. 3, no. 4, pp. 1-15, 2014.

[12] S. Sitharam and M. Hoque, "Factors affecting the performance of small and medium enterprises in KwaZulu-Natal, South Africa," Problems and perspectives in Management 14, no. 2 (2016): 277-288, vol. 14, no. 2, pp. 277-288, 2016.

[13] B. M. Pulka, B. R. Azahari and S. B. Muhammad, "Marketing capabilities, resources acquisition capabilities, risk management capabilities, opportunity recognition capabilities and SMEs performance: A proposed framework.," Asian Journal of Multidisciplinary Studies, vol. 6 , no. 1 , pp. 12-22, 2018 .

[14] I. M. Aminu and M. N. Shariff, "Influence of strategic orientation on SMEs access to finance in Nigeria," Asian Social Science, vol. 11, no. 4, p. 298, 2015. 
[15] A. Turyahebwa, A. Sunday and D. Ssekajugo, "Financial management practices and business performance of small and medium enterprises in western Uganda," African Journal of Business Management, vol. 7, no. 38, pp. 3875-3885, 2013.

[16] F. Demir and M. Caglayan, "Firm productivity, exchange rate movements, sources of finance and export orientation," Munich Personal Repec Archive, Munich, 2012.

[17] Y. Gorodnichenko and M. Schnitzer, "Financial constraints and innovation: Why poor countries dont catch up," Journal of the European Economic Association, vol. 11, no. 5, pp. 1115-1152, 2013.

[18] P. H. Hsu, X. Tian and Y. Xu, "Financial development and innovation: Cross-country evidence," Journal of Financial Economics, vol. 112, no. 1, pp. 116-135, 2014.

[19] R. Levine, C. Lin and L. Wei, "Insider trading and innovation," The Journal of Law and Economics, vol. 60, no. 4, pp. 749-800., 2017.

[20] I. O. Nnodim, B. C. Onuoha and R. S. Needorn, "The Effect of Product and Process Innovation Capabilities on the Competitiveness of Nigerian Quoted Banks," International Academy Journal of Management, Marketing \& Entrepreneurial Studies, vol. 8, no. 1, pp. 1-10, 2020.

[21] I. Sadalia, H. Muharan and A. Mulyana, "Entrepreneurial Orientation And Innovation To Competitive Advantage Of Smes In North Sumatera Mediated With Business Financing Factor," Journal of Critical Reviews, vol. 7, no. 1, pp. 136-140, 2020.

[22] A. T. Nafiu, H. Uba and E. M. Egwu, "Innovations, Competitive Advantage And Performance Of Small And Medium Size Enterprises In Kogi State: An Empirical Investigation," International Journal of Advanced Research, vol. 8, no. 4, pp. 23-31, 2020.

[23] M. S. Oladimeji, O. A. Amida and E. A. Essien, "Business Innovation and Competitive Advantage in Nigerian Manufacturing Sector," Emerging Markets Journal, vol. 9, no. 2, pp. 37-43, 2019.

[24] O. D. Ojo, M. Petrescu, A. G. Petrescu and F. R. Bilcan, "Impact of innovation on the entrepreneurial success: Evidence from Nigeria," African Journal of Business Management, vol. 11, no. 12, pp. 261-265, 2017.

[25] D. A. Adesoga, U. A. Olalekan, G. M. Olubisi and E. O. Abiodun, "Strategic Marketing, Innovation Culture and Competitive Advantage of Selected Petroleum Products Marketing Companies: Evidence from Nigeria," Journal of Business and Management, vol. 22, no. 3, pp. 60-70, 2020.

[26] M. G. Ukpabio, T. O. Oyebisi and O. W. Siyanbola, "Effects of Innovation on Performance of Manufacturing SMEs in Nigeria: An empirical study," A Publication of the Obafemi Awolowo University, Ife, Nigeria, pp. 1-19, 2019.

[27] W. R. Kerr and R. Nanda, "Financing innovation," Annual Review of Financial Economics, vol. 7, no. 1, pp. 445-462, 2015.

[28] V. Rysin, O. Galenko, N. Duchynska, N. Kara, O. Voitenko and A. Shalapak, "Financial Convergence as a Mechanism for Modifying Sectors of the Global Financial Services Market," Universal Journal of Accounting and Finance, vol. 9, no. 1, pp. 65-73, 2021. DOI: 10.13189/ujaf.2021.090107.
[29] Sołoducho-Pelc, Letycja and A. Sulich, "Between Sustainable and Temporary Competitive Advantages in the Unstable Business Environment," Sustainability, vol. 12, no. 21, p. $8832,2020$.

[30] C. Reguia, "Product innovation and the competitive advantage," European Scientific Journal, vol. 1, no. 1, pp. 140-157, 2014.

[31] Y. Gorodnichenko, J. Svejnar and K. Terrell, "Globalization and innovation in emerging markets," American Economic Journal: Macroeconomics, vol. 2, no. 2, pp. 194-226, 2010.

[32] M. E. Porter, Competitive advantage of nations: creating and sustaining superior performance, Boston: Free Press; Illustrated edition, 2011.

[33] T. Veronicah, R. Boit and M. Korir, "Incremental Innovation And Firm's Competitive Advantage: A Quantitative Analysis Approach," International Journal of Quantitative and Qualitative ResearchMethods, vol. 5, no. 1, pp. 22-30, 2017.

[34] S. W. Floyd and P. J. Lane, "Strategizing Throughout the Organization: Managing Role Conflict in Strategic Renewal," Academy of Management Review, vol. 25, no. 1, pp. 154-177, 2000.

[35] C. Amonini, J. R. McColl-Kennedy, G. N. Soutar and J. C. Sweeney, "How professional service firms compete in the market: an exploratory study," Journal of Marketing Management 26, vol. 1, no. 2, pp. 28-55, 2010.

[36] S. Kang and Y. K. Na, "Effects of strategy characteristics for sustainable competitive advantage in sharing economy businesses on creating shared value and performance," Sustainability, vol. 12, no. 4, p. 1397, 2020.

[37] M. Al-Rousan and F. Qawasmeh, "The Impact of SWOT Analysis on Achieving a Competitive Advantage: Evidence from Jordanian Banking Industry," International Bulletin of Business Administration, vol. 6, no. 1, pp. 82-92, 2009.

[38] V. Tarus, R. Boit and M. Korir, "Incremental Innovation And Firm's Competitive Advantage: A Quantitative Analysis Approach. International," Journal of Quantitative and Qualitative Research Methods, vol. 5, no. 1, pp. 22-30, 2017.

[39] R. G. King and L. Ross, "Finance and growth: Schumpeter might be right," The quarterly journal of economics, vol. 108, no. 3, pp. 717-737, 1993.

[40] A. Philippe, H. Peter and L. Ross, Financial development and innovation-led growth, Handbook of Finance and Development, 2018, pp. 3-30.

[41] H. Zang and Y. C. Kim, "Does financial development precede growth? Robinson and Lucas might be right," Applied Economics Letters, vol. 14, no. 1, pp. 15-19, 2007.

[42] T. S. Bateman and S. A. Snell, Management: The New Competitive Landscope, 6th ed ed., New York: McGraw Hill, 2004.

[43] S. Iriyanto, Suharnomo, M. T. Hidayat and M. Anas, "Do Intangible Assets and Innovation Orientation Influence Competitive Advantages? A Case Study of SMEs in Indonesia," Universal Journal of Accounting and Finance, vol. 9, no. 1, pp. 105-115, 2021. DOI: 10.13189/ujaf.2021.090111. 
[44] J. L. Thompson, Strategy Management, 5th ed ed., London: Thomsom Learning, 2001.

[45] M. J. Manimala and S. Kumar, "Training needs of small and medium enterprises: Findings from an empirical investigation," IIM Kozhikode Society Management Review, vol. 1, no. 2, pp. 97-110, 2012.

[46] N. Southiseng and J. Walsh, "Competition and management issues of SME entrepreneurs in laos: Evidence from empirical studies in vientiane municipality, Savannakhet and Luang Prabang," Asian Journal of Business Management, vol. 2, no. 3, pp. 57-72, 2010.

[47] E. Aykan, S. Aksoylu and E. Sönmez, "Effects of support programs on corporate strategies of small and medium-sized enterprises," Procedia - Social and Behavioral Sciences, vol. 99, pp. 938-946, 2013.

[48] I. Gisip and H. Harun, "An assessment of government support programs in the development of SMEs in Malaysia: Issues and challenges," Scottish Journal of Arts, Social Sciences and Scientific Studies, vol. 8, no. 2, pp. 9-18, 2013.

[49] T. T. Onileowo, "Motivational Factors of Women Entrepreneurs in Ado, Ekiti State: An Empirical Appraisal," World Journal of Entrepreneurial Development Studies, vol. 4, no. 1, pp. 2695-2483, 2019.

[50] A. Beyene, "Enhancing the competitiveness and productivity of small and medium scale enterprises (SMEs) in Africa: An analysis of differential roles of national governments through improved support services," Journal of Global Strategic Management, vol. 27, no. 3, pp. 130-156, 2002.

[51] A. J. van Stel, D. J. Storey and A. R. Thurik, "The effect of business regulations on nascent and actual entrepreneurship," 2006.

[52] R. Kiraka, K. Margaret and M. K. Allan, "Micro, small and medium enterprise growth and innovation in Kenya: A case study on the Women Enterprise Fund," 2015.

[53] O. R. Mahdi, M. K. Almsafir and L. Yao, "The role of knowledge and knowledge management in sustaining competitive advantage within organizations: A review," African Journal of Business Management, vol. 5, no. 23, pp. 9912-9931, 2011.

[54] H. M. Beheshti, "Gaining and sustaining competitive advantage with activity based cost management system," Industrial Management \& Data Systems, vol. 104, no. 5, pp. 377-383, 2004.

[55] N. C. Ito, P. H. Junior, F. A. P. Gimenez and J. E. Fensterseifer, "Value and competitive advantage: searching for definitions, relationships, and repercussions," RAC-Revista de Administração Contemporânea Journal of Contemporary Administration, vol. 16, no. 2, pp. 290-307, 2012.

[56] M. E. Porter, From competitive advantage to corporate strategy, Palgrave, London: Readings in strategic management, Springer, 1989, pp. 234-255.

[57] N. N. A. Aziz and S. Samad, "Innovation and competitive advantage: Moderating effects of firm age in foods manufacturing SMEs in Malaysia," in Procedia Economics and Finance, 2016.
[58] V. V. Acharya, H. Almeida and M. Campello, "Aggregate risk and the choice between cash and lines of credit," The Journal of Finance, vol. 68, no. 5, pp. 2059-2116, 2013.

[59] B. Honig, T. Karlsson and G. Hägg, "The Blessing Of Necessity And Advantages Of Newness (Summary)," Frontiers of Entrepreneurship Research, vol. 33, no. 14, p. 7, 2013.

[60] R. G. Fichman, "The role of aggregation in the measurement of information technology-related organizational innovation," Management information systems Quarterly, vol. 25, no. 4, pp. 427-455, 2001.

[61] M. A. Hitt, D. R. Ireland and R. B. Hoskisson, "Administração estratégica: competitividade e globalização," São Paulo: Pioneira Thomson Learning, 2002 .

[62] E. L. Paiva, J. M. Carvalho, Jr and J. E. Fenstersei, "Estratégia de produção e operações," Porto Alegre: Bookman, 2004.

[63] G. Saloner, A. Shepard and J. Podolny, Strategic Management., New York: John Wiley \& Sons, 2001.

[64] R. Rajan and L. Zingales, "Financial dependence and growth," American Economic Review, vol. 88, no. 3, pp. 559-586, 1998.

[65] F. T. Rothaermel, Strategic Management, Concepts and Cases, New York: McGraw Hill/Irwan, 2013.

[66] J. Sentsho, J. T. Maiketso, M. Sengwakets, V. N. Anderson and T. Kayawe, Performance and Competitiveness of Small and Medium Sized Manufacturing Enterprises in Botswana, Gaborone, Botswana: BIDPA, 2007.

[67] L. Stevenson and A. Lundström, "Entrepreneurship policy for the future: best practice components," in In proceedings of the 46th World Conference of the International Council for Small Business, 2001.

[68] D. J. Kelley, S. Singer and M. Herrington, "The global entrepreneurship monitor. 2011 Global Report, GEM 2011, 7.," Global Entrepreneurship Research Association, London, 2012.

[69] K. E. Okundaye, "Adoption of information and communication technology in nigerian small-to medium-size enterprises," Walden ScholarWorks, Minneapolis, Minnesota, 2016.

[70] OECD, "Oslo manual: Guidelines for collecting and interpreting innovation data (3rd ed.)," Statistical Office of the European Communities, and Society for International Development., Paris, 2005

[71] A. Hyytinen and O. Toivanen, "Do financial constraints hold back innovation and growth? Evidence on the role of public policy," Research Policy, vol. 34, no. 9, pp. 1385-1403, 2005.

[72] P. Aghion, N. Bloom, R. Blundell and R. Griffith, "Competition and innovation: an inverted-U relationship," The Quarterly Journal of Economics, vol. 120, no. 2, pp. 701-728, 2005.

[73] R. Morck and M. Nakamura, "Banks and corporate control in Japan," Journal of Finance, vol. 54, no. 1, pp. 319-339, 1999. 
[74] J. B. Ang, "Financial development, liberalization and technological deepening," European Economic Review, vol. 55, no. 5, p. 688-701, 2011.

[75] N. Barbosa and A. Faria, "Innovation across Europe: How important are institutional differences?," Research Policy, vol. 49, no. 9, pp. 1157-1169, 2011.

[76] K. E. Maskus, R. Neumann and T. Seidel, "How national and international financial development affect industrial R\&D," European Economic Review, vol. 56, no. 1, p. 72 83, 2012.

[77] R. P. Pradhan, M. B. Arvin, J. H. Hall and M. Nair,
"Innovation, financial development and economic growth in Eurozone countries," Applied Economics Letters, vol. 23, no. 16, p. 1141-1144, 2016.

[78] C.-Y. Ho, S. Huang, H. Shi and J. Wu, "Financial deepening and innovation: The role of political institutions," World Development, vol. 109, pp. 1-13, 2018.

[79] M. Porter, "Technology and competitive advantage," Journal of business strategy, vol. 5, no. 3, pp. 60-78, 1985.

[80] J. A. Schumpeter, The Theory of Economic Development, tenth ed., New Brunswick: New Brunswick: Transaction Publishers, 2004. 